\title{
MOTIVES OF SOCIAL MEDIA USAGE AND EFFECTS TO HOUSEWIVES WELL-BEING IN CIREBON CITY INDONESIA
}

\author{
Farida Nurfalah ${ }^{1}$, Norsiah Abdul Hamid², Mohd Sobhi Ishak ${ }^{2}$, Sabrina Mohd Rashid ${ }^{2}$ Nurudin $^{1}$ \\ ${ }^{1}$ Universitas Swadaya Gunung Jati, ${ }^{2}$ Utara Malaysia of University \\ faridan774@gmail.com/nor1911@uum.edu.my
}

Women dominate in general, they beat men on social media as on Facebook, Instagram and Twitter. Although the literature on motives for using social media is dominated by women, the findings do not fully reflect the motives among Indonesian housewives to use social media due to some costs. This study explores the motives of housewives about the use of social media and its effects on their well-being. This study adopted a mixed methods approach. The survey was chosen through snowball sampling. The results of the study explained that 1). The identities of housewives who use social media in Indonesia are mostly from Cirebon, living in Cirebon district, with a Bachelor's degree, with a home content income of Rp. 5,000,000., And above with tree households living in the same house. The use of social media in the form of Whatsapp and Instagram, with a usage time of about five hours. 2). Motivation of housewives uses social media social as a communication medium in interacting social with other social media users. 3). The impact of the use of social media among housewives, they can support each other and share whatever activities they do, look for health tips and tips on taking care of the household which in the end they live and enjoy their daily activities, can interact well through social media, carrying out important activities, they can overcome their problems well, live a good life, believe in their future, believe that they are respected by others. Their feelings are often positive and often good, often pleasant, often joyful, and never angry.

Keywords: social media, motives, flourishing, housewives, women.

\subsection{Backgrounded}

"Undoubtedly, social media is one of the fastest growing segments on the web" (Parra-López, BulchandGidumal, Gutiérrez-Taño\&Díaz-Armas, 2011). "Among the most popular applications of social media are weblogs or blogs (i.e. Blogger and WordPress), social networking sites (i.e. Facebook, Twitter and MySpace), photos and videos (i.e. Instagram, Flickr and YouTube), online encyclopaedia (i.e. Wikipedia), online bookmarking (i.e. Delicious), virtual social worlds (i.e. Second Life) and virtual game worlds (i.e. World of Craft)". These social media is also used for platforms allow users for search, create, share, collaborate and organise contents among them while at the same time provide virtual self-presentation and self-disclosure of oneself.

\begin{tabular}{|c|c|c|}
\hline \multicolumn{3}{|c|}{$\begin{array}{l}\text { Social Networks on Which US Internet Users Have } \\
\text { Accounts, by Gender, March } 2013 . \\
\% \text { of Respondents in each group }\end{array}$} \\
\hline & Female & Male \\
\hline Facebook & $56,0 \%$ & $49,5 \%$ \\
\hline Google+ & $26,1 \%$ & $24,5 \%$ \\
\hline Pinterest & $21,9 \%$ & $4,8 \%$ \\
\hline Twitter & $16,9 \%$ & $15,5 \%$ \\
\hline Linkedin & $14,2 \%$ & $14,4 \%$ \\
\hline Instagram & $6,1 \%$ & $5,7 \%$ \\
\hline Other & $7,4 \%$ & $7.6 \%$ \\
\hline \multicolumn{3}{|c|}{$\begin{array}{l}\text { Note }: \mathrm{n}=2,577 \text { ages } 18+ \\
\text { Source : Bust Media, "Expanding The Conversation } \\
\text { : Leveraging Social Media for Brand Interaction, } \\
\text { May } 17,2013\end{array}$} \\
\hline
\end{tabular}

Volume 24 - Issue 2 
Thus far, the usage of social media is recorded not for positive context per se, and it involved incremental figure in financial commitment. Consumers, including women, spend a huge amount of money for fee subscription, monthly charges, etc, but mostly for leisure, entertainment, and social purposes (Malaymail Online, August 2016) ${ }^{2}$. This is also true for housewives who are active users of social media, which bring us to the questions of why they spent money on social media and for what reasons? The problem raised is how to motive the use of social media for housewives and their effect on their quality of life are also being emphasized by Divatia and Patel (2017).Hoffman and Novak (2012) urged the Internet is used positively for well-being, yet it is unclear under what conditions beneficial effects for social media and their daily lives. In addition, many studies focused on younger social media users such as university students (e.g. Hamid, Ishak\&Yazam, 2015) ${ }^{3}$, and children (Rahi, 2016) ${ }^{4}$ but not many put focus on women and housewives and but not many focus on women and housewives and also research on the same thing in in Indonesia is still limited.The use of social networking paths by housewives conducted (Wulandari et al, 2014: 115) ${ }^{5}$. That social networking path is used by housewives for pleasure, which includes the fulfillment of self-existence for the user and entertainment when they feel fed up with everyday, forms of interaction which includes discussion about childcare patterns with other users. As well as the Path they use to interact with the outside world, Path is able to meet the needs of informants in terms of developing information. It can be said that Path is a gathering event for housewives in Bandung who are informants in research.

Lacking of confidence among housewives in utilizing social media to enhance their economic stability has also hindered opportunities in moving forward. Given the right guidance and information, housewives are among those who can benefit from this phenomenon (Ging, 2015) ${ }^{6}$. Steering business through social media platforms such as Facebook and Instagram has been mounting the past few years with everybody from multinationals to home bakers cashing in on this unconventional method of reaching new customers online. In this study more focused on their mood after using social media, so it will also be seen the impact on housewife activities.

\subsection{Research Purpose}

This research intends to find motivations of housewives to used social media also its effects to their wellbeingin the districk of Cirebon, Indonesia. The objects in this study are as follows:

1. To identify social media user profile by housewives in Cirebon, Indonesia.

2. To investigate the motives of social media usage among housewives in Cirebon, Indonesia.

3. To assess the effects of social media usage among housewives in Cirebon, Indonesia.

\subsection{LITERATURE STUDY}

\subsubsection{Introduction to Literature Review}

"Social media is very well know by users, in expensive, scalable internet and mobile based technologies that allow for the sharing of user-generated materials" (Fischer \& Reuber, 2010) ${ }^{7}$ Kim, Jeong and Lee specifically $(2010)^{8}$ the term from social web sites that "those web sites that make it possible for people to form online communities, and share user-created contents (UCC)" (p.216). Nevertheless Kaplan and Haenlein (2010) $)^{9}$ argues that it is different from the two concepts. Kietzmann, Hermkens, McCarthy and Silvestre (2011) ${ }^{10}$ classified social media into seven blocks, namely identity, conversations, sharing, presence, relationships, reputation and groups. They proposed these blocks for firms as well as individuals to manage risks and opportunities in social media offerings.

The use of social media for women and girls has increased compared to men and boys (Hicks, 2010) ${ }^{11}$; (Lenhart, 2009) $^{12}$; Maul, 2010) ${ }^{13}$. A Google survey of 17 social networks in 2009 found that male users dialed female numbers, Digg, a social news site (Hicks, 2010) ${ }^{14}$. The gender balance is the same in only two, LinkedIn and YouTube. Women make up 57 per cent of Facebook and Twitter, 64 per cent of MySpace, and 68 per cent of Bebo. A fact sheet published by Pew Internet Research in $12^{\text {th }}$ January 2017 (Pew Internet Research, 2017) ${ }^{15}$ revealed that women outnumbered men in Facebook Instagram and Pinterest usage, while men only conquer the LinkedIn, while Twitter equal.

However, studies also found that women suffered more from the used of social media compared to men. For instance, Sei-Ching $(2016)^{16}$ found that women were more affected with social media which include too much information, conflicting information, and non-credible information, while men were more affected by irrelevant information and outdated information.Al-Saggaf's $(2017)^{17}$ study on female users found more lonely users revealed sensitive and non-sensitive information on Facebook as compared tonot-lonely female users. More female users who indicated in their relationship status that they were single were revealed to be lonely than not-lonely. 
Odine (2013) $)^{18}$ "Women have to get involved in utilizing social media quickly, integrating with people like Facebook, Twitter, and the Internet which is very powerful in devices such as smartphones, iPads, laptops, and desktop computers. Smart and smart housewives must look for new knowledge and ways to improve their decision-making abilities, and find ways to improve their abilities or even change family attitudes if necessary." (Divatia\& Patel, 2017) ${ }^{19}$.

\subsubsection{Uses and Gratification Theory}

This study uses the Theory of Use and Gratification (U\&G) to investigate the motives of housewives in using social media and their effects on their own well-being. The use and gratification perspective places a great deal of emphasis on the active role of the audience in making choices and is directed towards their goals in the behavior of social media use (Blumler, 1979) 20; (Blumler \& Katz, 1974) 21; (Palmgreen, 1984) 22; (Rosengren, Wenner) 23, \& Palmgreen, 1985; (A.M.Rubin, 2002) 24; (A.M.Rubin \& Windahl, 1986) 25; Windahl, 1981) 26. The experience and effects of media depend on the use of media usage and the satisfaction they receive (Harris, 2008) 27. Thus, U\&G is the most relevant theory for studying the motives of using social media for housewives and what they appreciate from the media.

\subsubsection{Motives of Social Media Usage}

Quite a number of studies focused on the motives of using specific tools of social media. For instance, Instant Messenger (IM) and Facebook possess a similar factor structure, suggesting that they have very similar uses and fulfill similar communication and socialization needs (Quan-Haase\& Young, 2010) ${ }^{28}$. Both tools are used primarily as a pastime activity: to have fun, to kill time, to relax, and to provide a form of escape from everyday pressures and responsibilities.

SNSs are predominantly used for social purposes (Alhabash, Park, Kononova, Chiang \& Wise, 2012) ${ }^{29}$; (Kuss\&Griffiths, 2011) ${ }^{30}$; (Tanta, Mihovilović\&Sablić, 2014) ${ }^{31}$. Extraverts appear to use social networking sites for social enhancement, whereas introverts use it for social compensation, each of which appears to be related to greater usage, as does low conscientiousness and high narcissism (Kuss\&Griffiths, 2011). Most adolescents use Facebook for socializing and communicating with their friends, discussing school activities, setting up meetings and dates with friends as well as obtaining information about social events (Tanta, Mihovilović\&Sablić, 2014). The use of Facebook primarily gratifies adolescents' need for integration, social interaction, information and understanding of their social environment.

Likewise, Alhabash, Park, Kononova, Chiang and Wise (2012) found that motivation to use Facebook to post and view status updates is the strongest predictor of Facebook's intensity, while the motivation to view and share photos is the strongest predictor of content generation behavior on sites. Their findings also indicate that the highest ranking motivation for using Facebook is social relations. This serves to describe the universal utility of SNS and how they develop in different cultures.

Meanwhile, Whiting and Williams (2013) ${ }^{32}$ "found ten uses and satisfaction using social media, namely: to interact socially, information search, past time, entertainment, relaxation, communication utilities, comfort, expression of opinions, information sharing, and supervision / knowledge about other people". Cheung (2014) "found positive motives related to use and self-presentation, while the number of followers was also clarified as having a positive correlation with Instagram use and self-presentation. Their results also show that most students use Instagram every day and this shows that using Instagram has become part of their daily routine and affects their daily lives".

A number of researchwas done on housewives usage of social media. Tripathi and Al Shahri $(2016)^{34}$, for instance, studied the pattern of social media usage among Omani's housewives. The result proved that Omani housewives have explored new dimension of career by using social media without going for a job. Divatia and Patel $(2017)^{35}$ "found that housewives like Whatsapp, Facebook and YouTube the most, but very likely to use Skype. They also found that housewives prefers to do all the household chores and then they use their time to interact using the internet".

The Asian parent.com's survey concluded that "more that more than $80 \%$ of women in Singapore, Thailand, Malaysia and Indonesia turn to the Internet for friendship after they become full-time housewives." (as cited in Divatia \& Patel, 2017). "The 2014 Asian Digital Mum survey also revealed that mothers gradually use their smartphones to check email, visit parenting sites and use social media. They are also the main decision makers when it comes to household purchases". (Barthwal, 2014) ${ }^{36}$.

\subsubsection{Social Media and Well-being}

"A number of studies have considered aspects of personal development, transformation, and self-actualization of social media that are relevant to eudemonic well-being. Eudemonia is an Aristotelian term for "human growth" 
(Coghlan, 2015) ${ }^{37}$ Diener, Wirtz, Tov, Kim-Prieto, Choi, Oishi, and Biswas-Diener (2010) ${ }^{38}$ proposed two new measures of well-being, and early psychometric support for thesis scale. First, they offer a measure of psychosocial development, based on the latest theories about psychological and social well-being. Second, a new scale for assessing positive and negative feelings (SPANE) is proposed and has certain advantages over the past scale designed for this purpose. Both scales show strong psychometric characteristics".

Hofman and Novak (2012) $)^{39}$ utilizes Diener's (2010) scale and they found flourishing are highest for individuals whose primary social media goal is to create, while those whose primary social media goal is to connect are happiest with their overall social media use. Tong dan Wang (2017) ${ }^{40}$ "found that the scale of growth and SPANE showed adequate compatibility within the Chinese community, with gender and social status having an influence on growth. This research supports the idea that social media can be the vehicle at the best level, although the long-term impact is unclear".

\subsection{Methods}

This research uses a mixed methods approach consisting of cross-sectional online surveys and focus groups. Survey participants were selected through snowball sampling and the main criteria for selecting respondents were housewives who actively used social media in their daily lives and were reachable by researchers through snowball techniques. Questionnaires are distributed through online and / or printed web surveys.'The instrument for this survey was in the form of a questionnaire consisting of sections including respondents' demographic profiles, and constructs which were adapted from two main references, namely Motive for Using Social Media" by Yang and Liu (2017) ${ }^{41}$, and Growth Scale and Positive Scale and Negative Experience ( SPANE) by Diener, Wirtz, Tov, Kim-Prieto, Choi, Oishi, and Biswas-Diener $(2010)^{42}$. Instrument development consists of a 5-point Likert-type scale $(1=$ Strongly Disagree to 5 $=$ Strongly Agree). All questionnaires are tested first to ensure validity and reliability are met.

All questionnaires are tested first to ensure validity and reliability are met. Structural Equation Modeling (SEM) through the SPSS software package used for data analysis. The suitability index includes the Chi-Square statistic divided by the level of freedom (x2 / df); Root Mean Square Error of Approximation (RMSEA), SRMR, Parsimony Normed Fit Index (PNFI), and Comparative Fit Index (CFI) as suggested by Hair, Black, Babin and Anderson (2010) ${ }^{43}$, and TabachnikandFidell $(2001)^{44}$. As for seeing the correlation, it can be seen that the correlation of 0.543 with a significance value of 0.00 which is smaller than the probability of 0.05 , then there is a relationship and sig. (2-tailed) then there is a positive effect. (singgih, 2014: 265$)^{45}$

To strengthen the research design, a focus group discussion will be conducted with the housewives in the province of Cirebon, Indonesia to examine their views on the utilization of social media in their daily lives. The general characteristics of focus group include the homogeneity of the group, the sequence of the sessions, the obtaining of qualitative data, and focus on a topic (Freitas, Oliveira, Jenkins \&Popjoy, 1998) ${ }^{46}$. They are also useful in generating a rich understanding of participants' experiences and beliefs (Gill, Stewart, Treasure \& Chadwick, 2008) ${ }^{47}$. Focus group guide will be developed based on the research objectives and the session will be conducted at the participant's place. Results of the focus group discussion will be transcribed and analyzed using thematic analysis.

\subsection{Result And Discutions}

1.5.1. Identify Social Media User Profile by Housewives in Cirebon, Indonesia.

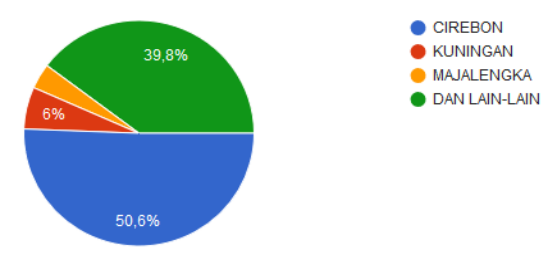

Housewives are mostly from Cirebon, which is around $50.6 \%$ (fifty point six percent) following others. This happens because many migrants from the three regions of Cirebon as well as from other regions such as Bandung, Jakarta, and even from outside Java who live in Cirebon. 


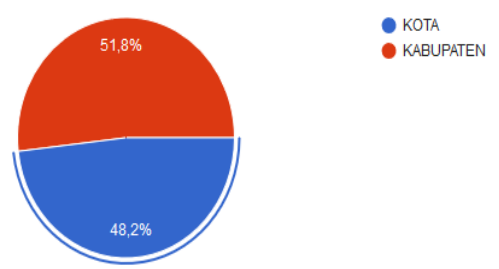

In this study, most informants live in Cirebon District, this happens because the area of Cirebon Regency is wider than Cirebon City which only has five Districts, while Cirebon District consists of 40 Districts.

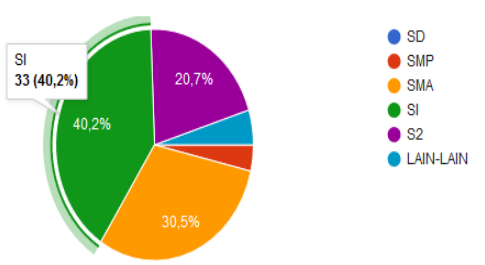

The level of education is very diverse, the majority of housewives in the city of Cirebon are bachelor graduates (S1), so housewives in Cirebon have good education, although there are still those with junior high school and elementary school education.
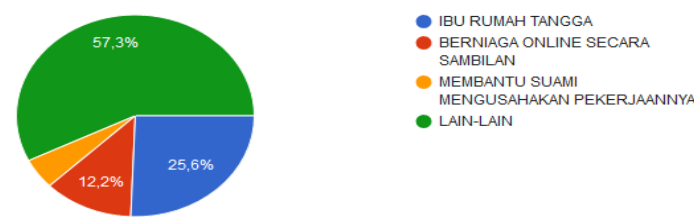

- LAIN-LAIN

The status of the majority of housewives who have other dominant identities is around $57 \%$ (fifty-seven percent) because when viewed from their educational background, they tend not to be pure housewives, but they have experience as career women.
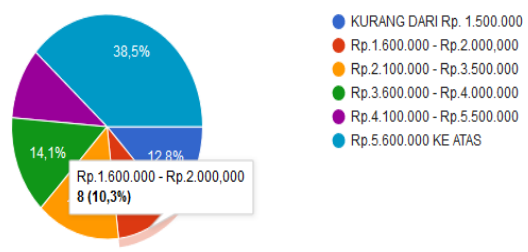

The unexpected thing is that the majority of household contents in their families have an income above Rp. $5,000,000$ (Five Million Rupiah). Thus, the majority of families in this study are families that can or can be said to earn enough income, although there are also those who earn below.

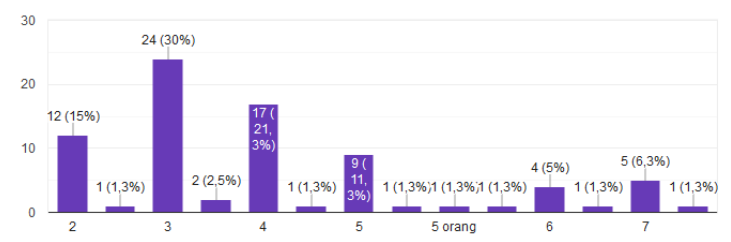

The number of families in this study who live in the same house is three and four, so the majority of their families have only one child and two children in accordance with the government program that two children are better or are now better known as two children.

\section{Volume 24 - Issue 2}




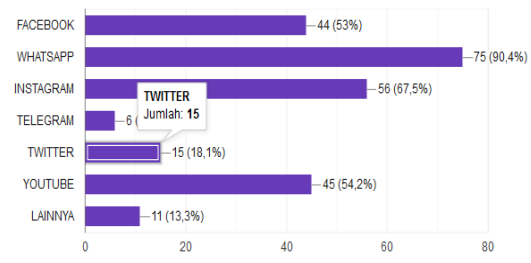

The majority of housewives in Cirebon interact with their environment using Whatsapp as a medium of communication and Instagram, as well as teenagers who also enjoy using social media. This is consistent with the results of previous studies and surveys.

Indonesia is mostly from Cirebon, living in Cirebon district, with a Bachelor's degree, with a home content income of Rp. 5,000,000., And above with 3 households living in the same house. The use of social media in the form of Whatsapp and Instagram, with a usage time of about five hours.

\subsubsection{The Motives of Social Media Usage Among Housewives in Cirebon, Indonesia}

Motivation of housewives in using social media which is more dominant as a medium of communication itself, namely in interacting socially with that environment in this case of course with fellow social media users as well.Following the results of his research :

"I use social media for relaxation from home workloads a lot"

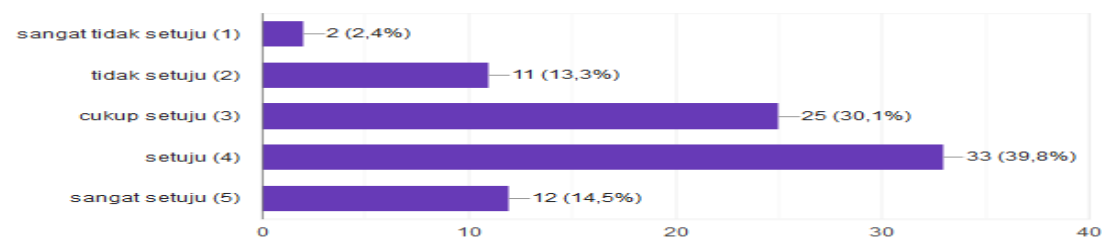

Housewives in Cirebon, for the most part, agreed and quite agreed that using social media for relaxation from the heavy workload of home. Basically everyone has their own routine, but based on the survey results that the statement of the Housewife in Cirebon who agreed to relax using social media can still be said to be low at around $39.8 \%$ (thirty nine point eight percent), then they use The motivation of social media is more dominant because of the social media's passion, namely as a medium of communication in interacting with the environment in this case with fellow social media users.

"I use social media to reduce anxiety about many problems"

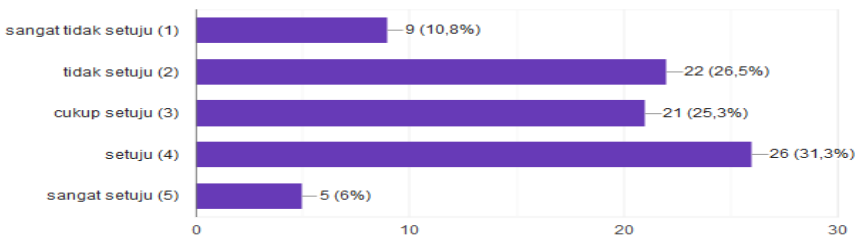

Like the previous statement, that housewives use social media more to the value of media communication with fellow users, not to reduce the concerns they face, this is because only $31.3 \%$ (thirty one point three percent) agree.

"I use social media to treat boredom every day"

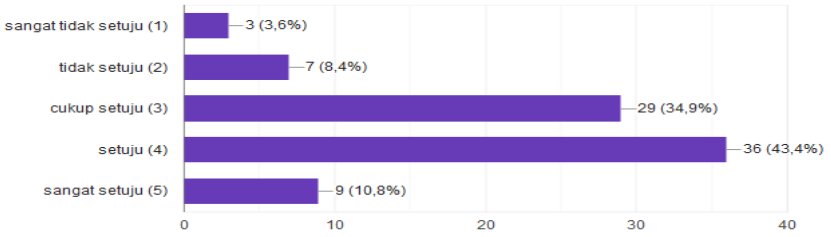

Volume 24 - Issue 2 
Likewise with treating boredom housewives in their daily lives, only $43.4 \%$ (four three point four percent) stated that they agree, so social media plays a role as a communication medium in housewives in Cirebon.

"I use social media to escape from real life"

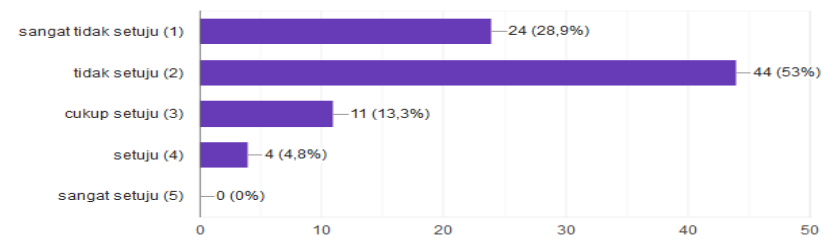

Other statements also said about 53\% (fifty-three percent) Housewives said they did not agree that they used social media to escape their real lives. Housewives in Cirebon utilize social media as their function, which is a means of communication in interacting with fellow users.

"I use social media to express feelings"

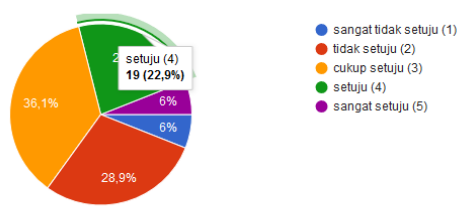

Similarities in using social media to express feelings, Housewife stated quite agree only $36.1 \%$ (three six point one percent). The use of Social Media in expressing feelings is only a complement, again that the main function of social media is a means to communicate.

"I use social media to let go of resentment"

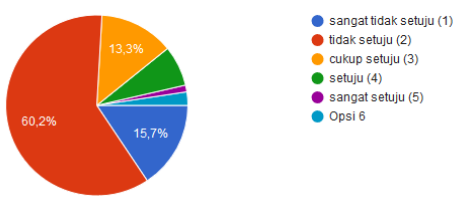

The same thing is also denied by housewives in Cirebon, that they disagree if they use social media to release their frustration. As many as $60.2 \%$ (sixty point two percent) they said they did not agree, their motivation to use social media was not to release resentment.

1.5.3. Assess the effects of social media usage among housewives in Cirebon, Indonesia

"I use social media to find out about fellow activities"

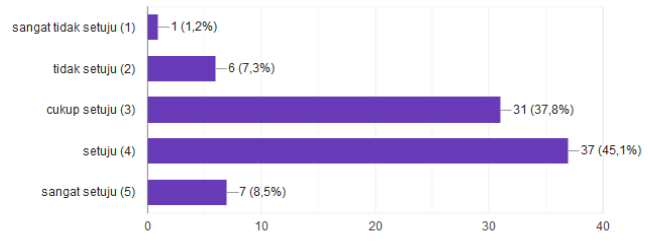

Based on the previous statement, the motivation of Housewives in Cirebon to use social media is not for negative things, but they use social media in accordance with their function, namely communication media in social with fellow users. As many as $45.1 \%$ (four five point one percent), they use social media to find out the activities of fellow social media users. This they do to support each other and share what activities they have, are or will do. 
"I use social media to look for recipes"

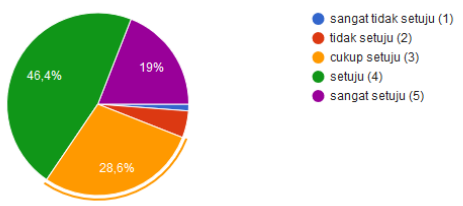

As a happy housewife is their priority. One of them is by serving delicious food. One of them is to look for recipes. As many as $46.4 \%$ (forty six point four percent) Housewives in Cirebon like to cook by finding food recipes through social media. It is feared that the culture of eating with family at home starts to be displaced by culinary outside the home because of the busyness between families and they want a more relaxed and more creative atmosphere. Lots of snacks or culinary found in Cirebon and even famous abroad.

"I use social media to look for tips on looking after children"

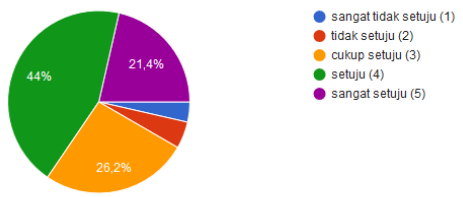

Statement of Housewives in Cirebon in using social media to look for tips on caring for children is only $44 \%$ (forty four percent) only. They are more likely to take care of children in sharing with family and friends during school because they each have experience.

"I use social media to find tips for maintaining personal health"

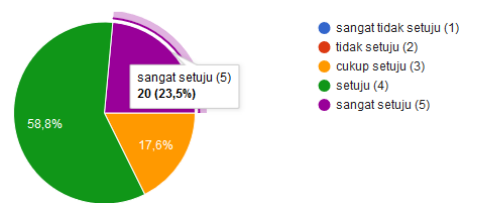

In contrast to health care tips, as many as $58.8 \%$ (fifty eight point eight percent) Housewives in Cirebon use social media to search for health tips, in fact many are found among social media groups such as whatsapp sharing about health with various versions and themes in share, especially regarding health in old age.

"I use social media to look for tips on taking care of the household"

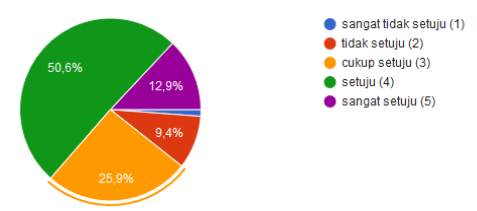

As many as $50.6 \%$ (fifty point six percent) Housewives use Social media to look for Tips to take care of the household, because the family is the main, they want to do anything for the family, one of them utilizing social media to find tips on taking care of the house stairs.

"I use social media to look for tips to take care of home finances"

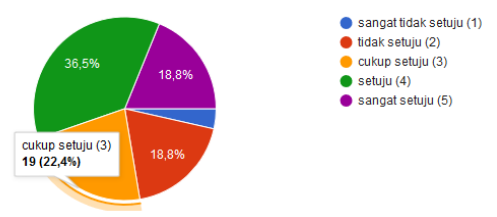

Volume 24 - Issue 2 
The link is looking for tips in managing home finances as much as $36.5 \%$ (thirty five point five percent) they use social media to take care of finances, this happens because in relation to taking care of finances they have their own car that they use, because of life and family size they can be said to be a middle-income family with three families, so it's not too complicated in managing family finances.

"I use social media to interact with anything"

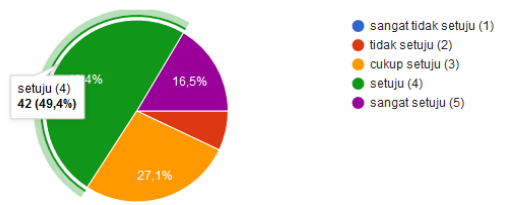

Use Social Media to interact with whatever housewives in Cirebon do. As many as 49.4\% (four nine point four percent) they use social media with a variety of interactions, so that the network through social media is very effective to be able to interact between fellow users.

\section{KNOWING FRIENDSHIP}

"I use social media to socialize with friends"

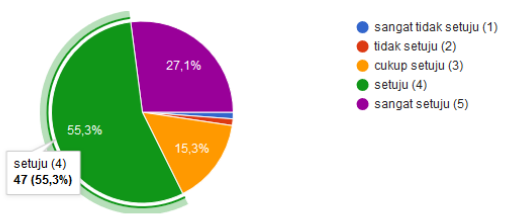

As many as 55.3\% of housewives in Cirebon agreed that they use social media to socialize with friends they know, old friends, now, and get acquainted when they meet in person or through social media.

"I use social media as a daily activity with friends"

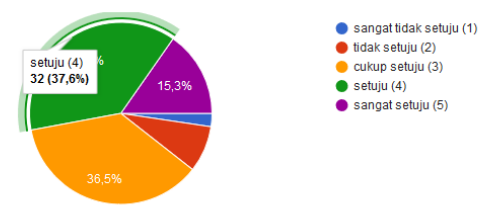

Social media as a daily activity with friends, housewives said they agreed with only $37.6 \%$, this explains that Housewives whose main activity is not only using social media, social media is only a complement in the daily activities of housewives in Cirebon.

"I use social media as a main activity that pleases my friends"

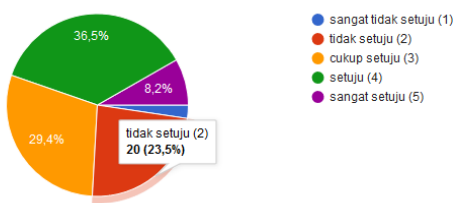

In relation to the main activity of pleasing his friends, Housewife only about $36.5 \%$ stated agreed. Social media is not the main activity in pleasing friends, so there are other activities in fun friends of Housewives in Cirebon. 


\section{CONSTRUCT NEW RELATIONSHIP}

"I use social media to find new friends"

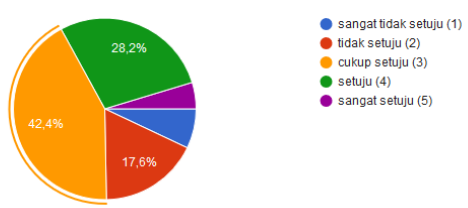

As many as $42.4 \%$ (forty two point four percent) Housewives said they quite agree this happened because Housewives have friends they previously knew. Social Media as their means to always be able to communicate with friends, so looking for new friends is not the main motive.

"I use social media to find friends who are have the same interests "

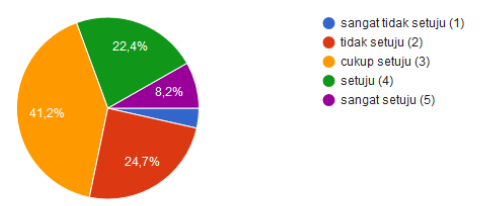

Likewise, looking for friends who have the same interest, not the main motive in using social media, this is proven because only 41.2 (four one point two percent) Housewives stated that they quite agreed. Social Media is used by them because they already have friends before.

"I use social media to interact with users other social media "

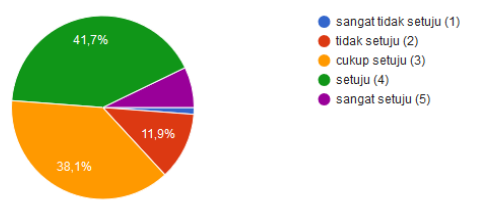

As many as 41.7 (forty-one point seven percent) Housewives agreed that the use of social media to interact with other social media users, this happened because of various motives of Housewives in using Social Media.

\section{NOSTALGIA}

"I use social media to restore the nostalgia of the past"
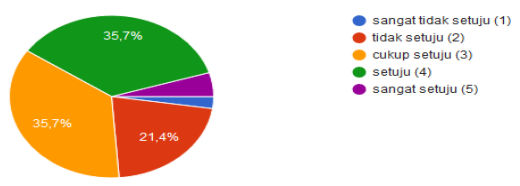

As many as $35.7 \%$ (three five point seven percent) Housewives use social media to restore past nostalgia with a statement that is quite agreeable, this is because looking for old friend contacts requires time to be able to communicate with old friends so as to create an atmosphere of nostalgic communication.

"I use social media to restore childhood memories"

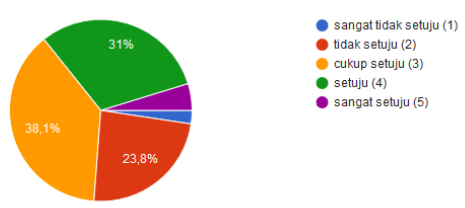

Similar to the previous statement, only about $38.1 \%$ (three eight point one percent) Housewife stated quite agree. This happens because Housewife activities are diverse, so to restore childhood memories is not the main thing through social media.

Volume 24 - Issue 2 
"I use social media to restore beautiful past memories"

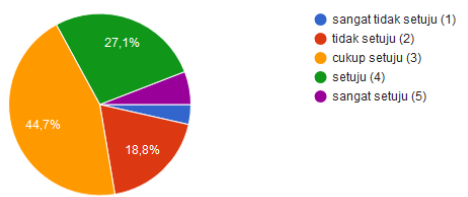

A good memory of the past through social media, Housewives in Cirebon said only $44.7 \%$ (forty four point seven percent) stated that they quite agreed. This happens because housewives in Cirebon only a small part of returning past memories through social media. This happens because social media emerged in millennial times.

"I use social media because it makes me feel young again"

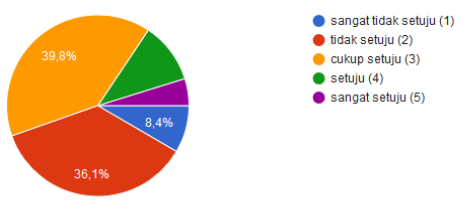

Housewives in Cirebon only 39.8\% (three nine point eight percent) said that agreeing enough to use social media made them feel young again. This happened because the age of the housewife was relatively early in her early age, so that the housewife kept abreast of the times by actively engaging in social media and just simply agreed to feel young again. The advantages of social media are high levels of interaction between users who have connections. Users can send comments to each other's posts or directly chat and send messages such as e-mail. When in the past mobile phones had the function of only calling and sending texts (SMS), now mobile phones also function as communication tools, cameras, video players and music to become a medium that connects people with the internet. As a result, mobile phones are now popping up with the term smartphone.

\section{PROSPERITY OF LIFE}

"Life is very meaningful to me"

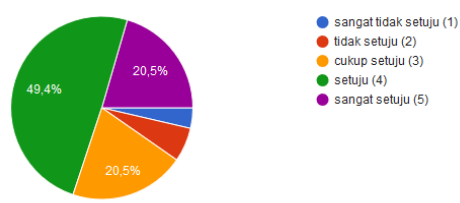

As many as $49.4 \%$ (four nine point four percent) Housewives in Cirebon feel quite agree that their lives are meaningful with the presence of social media. Social media can provide enough color in the daily life of Housewives in Cirebon.

"Social relations are a form of support which benefits me"

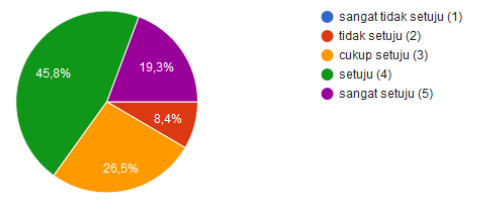

Social relations provide benefits for housewives in Cirebon, this has been proven as much as $45.8 \%$ (forty five point eight percent agreeing) Social media provides benefits for housewives in the city of Cirebon.

"I appreciate and enjoy my activities all day" 


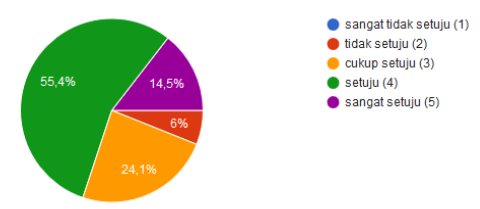

As many as $55.4 \%$ (fifty-five percent) Housewives in Cirebon stated to appreciate and enjoy their daily activities. They can interact well through social media.

"I contribute to the happiness of others"

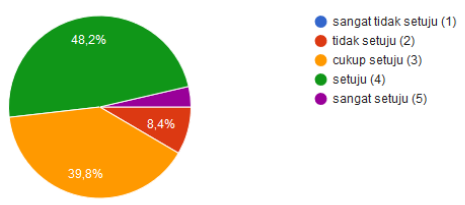

As many as $48.2 \%$ (forty eight point two percent) Housewives in Cirebon share happiness with others. Through social media they filter each other one of which is to share happiness between them.

"I am able to carry out important activities"

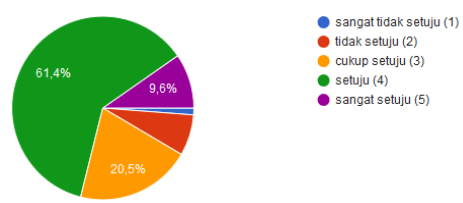

Housewives in Cirebon agree they can carry out important activities which are $61.4 \%$ (six one point four percent). They can overcome their problems well.

"I live a good life"

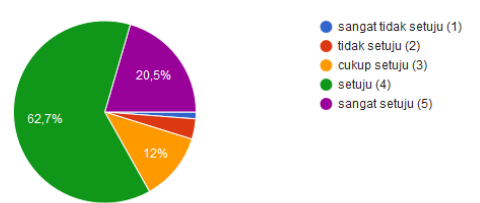

As many as $62.7 \%$ (sixty-two point seven percent) agreed that they could live a good life, this means they really enjoyed their lives with their family and environment as well as friends on their social media.

"I am confident in my future"

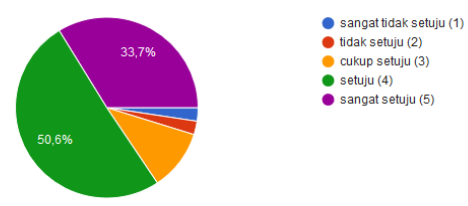

As many as $50 \%$ (fifty percent) they agree that they are confident in their future. Housewives in Cirebon have a good self-concept, they as a housewife can be a role model for their children and others.

"Other people respect me"

\section{Volume 24 - Issue 2}




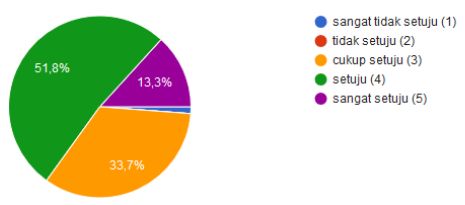

Other people respect them, this is explained that as much as $51.8 \%$ (five one point eight percent) they believe that they are respected by others.

\section{POSITIVE / NEGATIVE FEELINGS}

POSITIVE FEELINGS

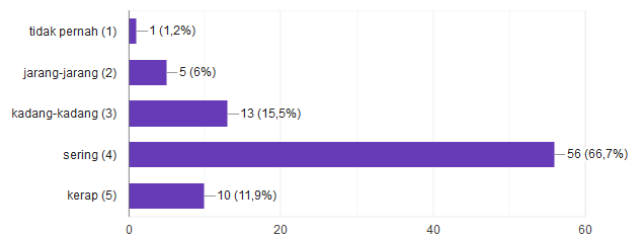

As many as $66.7 \%$ (sixty six point seven percent) their feelings are often positive, because they have a good selfconcept.

\section{NEGATIVE FEELINGS}

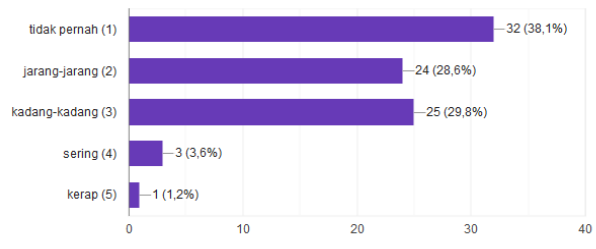

As many as $38.1 \%$ (thirty-eight point one percent) they do not agree that their feelings are never negative, they can interact, socialize with their environment properly.

WELL FEELINGS

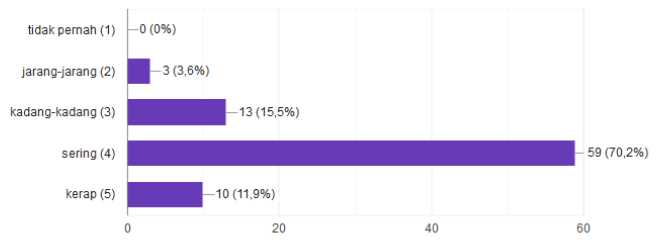

As many as $70.2 \%$ (seventy point two percent) they often feel good, so they feel good already.

\section{NOT GOOD FEELINGS}

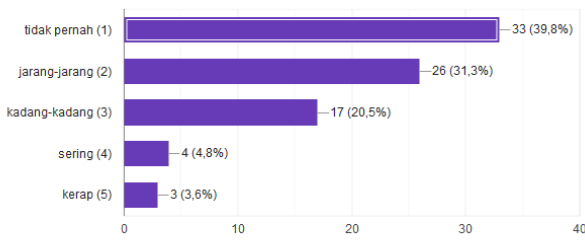

Volume 24 - Issue 2 
As many as $39.8 \%$ (three nine point eight) their feelings were never bad, so it's clear they feel good. IT'S FUN

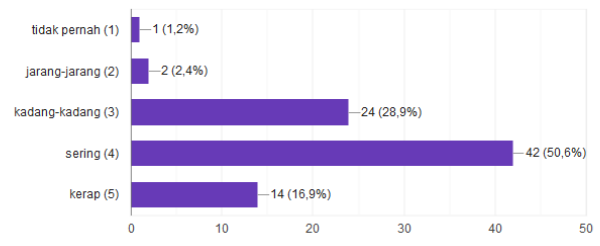

As many as $50.6 \%$ (fifty point six percent) their feelings are often pleasant, so their lives are fun . NOT FUN

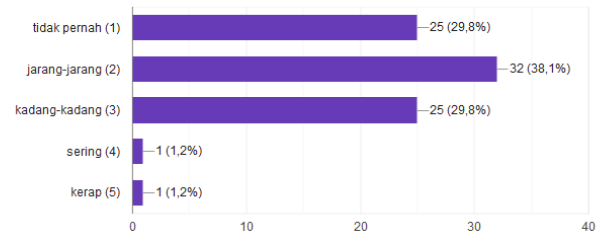

As many as $38.1 \%$ (seventy eight point one percent) their feelings are rarely unpleasant, because their lives are fun HAPPY

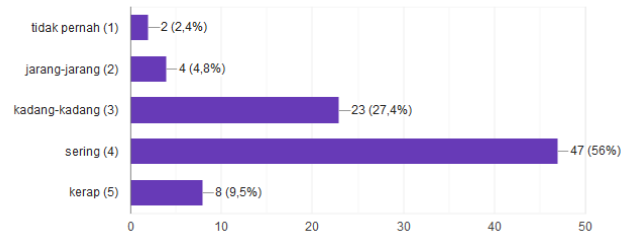

As many as $56 \%$ (fifty-six percent) of their feelings are often excited, because in their daily lives they deal with fun.

SAD

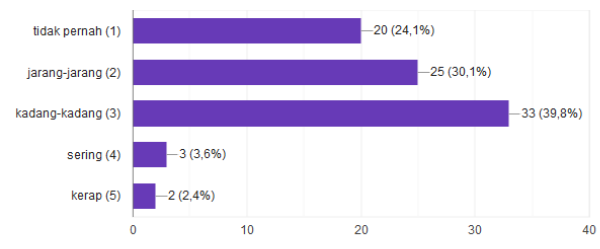

As many as $39.8 \%$ (three nine point eight percent) their feelings are sometimes sad, because they are often happy..

\section{WORRY}

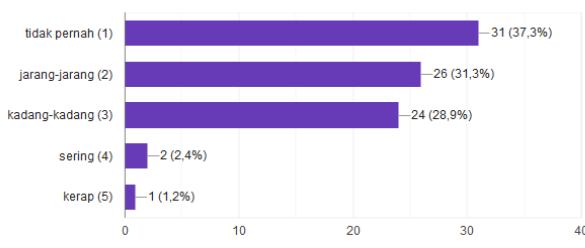

As many as $37.3 \%$ (thirty seven point three percent) their feelings were never wavering, because their lives are fun and happy.

Volume 24 - Issue 2 


\section{FREE}

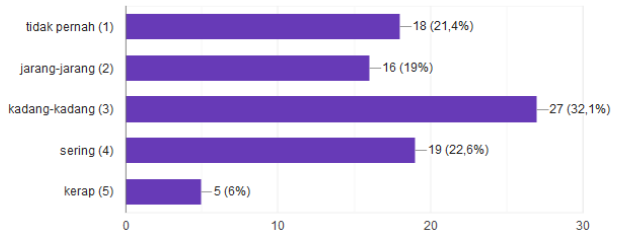

As many as $32.1 \%$ (thirty two point one percent) their feelings are sometimes free, because they are married. ANGRY

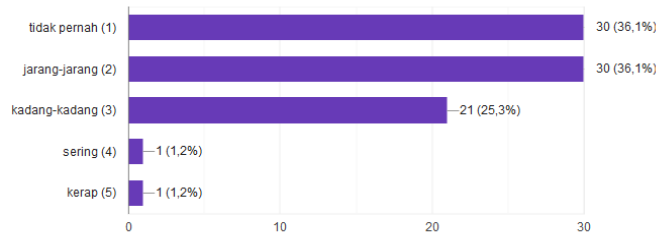

As many as $72.2 \%$ (seventy two point two percent) their feelings have never been and rarely get angry, because their lives are fun, happy and never wavering.

\section{SATISFIED}

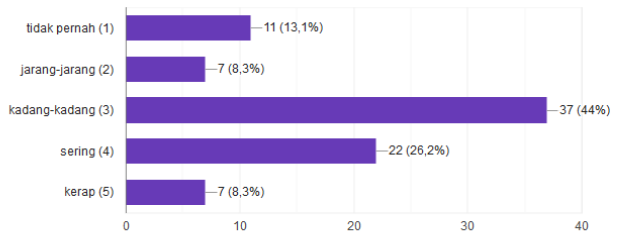

As many as $44 \%$ (forty-four percent) of their feelings are sometimes satisfied, because of life with various problems. That they can support each other and share what activities they have, are or will do. In addition, to look for health tips and tips on taking care of the household, in the end they appreciate and enjoy their daily activities, can interact well through social media, carry out important activities, they can overcome their problems well, live a good life, sure with their future, believing that they are respected by others. Their feelings are often positive and often good, often also pleasant, often happy, and never angry.Results of previous studies that the use of social networking paths by housewives conducted Wulandari et al 2014: 115. That social networking path is used by housewives for pleasure, which includes the fulfillment of self-existence for the user and entertainment when they feel fed up with everyday, forms of interaction which includes discussion about childcare patterns with other users. As well as the Path they use to interact with the outside world, Path is able to meet the needs of informants in terms of developing information. It can be said that Path is a gathering event for housewives in Bandung who are informants in research. In this study a different test was conducted The Paired Samples Test Results t-test. For the results of Paired Samples Test t-test the motives for using social media and the impact of using social media can be seen in the following table:

Table 1.1

\begin{tabular}{l|l|l|l|l|l}
\hline \multicolumn{9}{c}{ Paired Samples Statistics } \\
\hline & Mean & N & Std. Deviation & Std. Error Mean \\
\hline Pair 1 & VAR00001 & 78,4828 & 87 & 11,52940 & 1,23608 \\
\cline { 2 - 6 } & VAR00002 & 63,4368 & 87 & 9,16604 &, 98270 \\
\hline
\end{tabular}

A summary was obtained that the average motive for using social media was 78.5 while the impact of using social media was an average of 63,4 with a total of 87 respondents for a standard deviation of the motive 11.53 and the impact of using social media standard deviation for the impact of use social media 9.16, and the average value of the motives for using social media 78.48 and the impact of the use of social media 63.4, then descriptively there are significant differences with the standard error of the mean motive for using social media 1.23 and the impact use of social media 0.98 . 
Table 1.2

\begin{tabular}{l|l|l|l|l}
\hline \multicolumn{4}{c}{ Paired Samples Correlations } \\
\hline \multicolumn{2}{c|}{} & $\mathrm{N}$ & Correlation & Sig. \\
\hline Pair 1 & VAR00001 \& VAR00002 & 87 &, 534 &, 000 \\
\hline
\end{tabular}

As for seeing the correlation, it can be seen that the correlation of 0.543 with a significance value of 0.00 which is smaller than the probability of 0.05 , then there is a relationship and sig. (2-tailed) then there is a positive effect. (singgih, 2014: 265)

Table 1.3

\begin{tabular}{|c|c|c|c|c|c|c|c|c|c|}
\hline \multicolumn{10}{|c|}{ Paired Samples Test } \\
\hline & & \multicolumn{5}{|c|}{ Paired Differences } & \multirow[b]{3}{*}{$\mathrm{t}$} & \multirow[b]{3}{*}{ df } & \multirow{3}{*}{$\begin{array}{l}\text { Sig. } \\
\text { tailed) }\end{array}$} \\
\hline & & \multirow[b]{2}{*}{ Mean } & \multirow{2}{*}{$\begin{array}{l}\text { Std. } \\
\text { Deviation }\end{array}$} & \multirow{2}{*}{$\begin{array}{l}\text { Std. Error } \\
\text { Mean }\end{array}$} & $\begin{array}{l}95 \% \\
\text { Interval } \\
\text { Difference }\end{array}$ & $\begin{array}{l}\text { Confidence } \\
\text { of the } \\
\end{array}$ & & & \\
\hline & & & & & Lower & Upper & & & \\
\hline $\begin{array}{l}\text { Pair } \\
1\end{array}$ & $\begin{array}{l}\text { VAR00001 } \\
\text { VAR00002 }\end{array}$ & $\begin{array}{l}15,045 \\
98\end{array}$ & 10,20135 & 1,09370 & 12,87177 & 17,22018 & $\begin{array}{l}13,75 \\
7\end{array}$ & 86 &, 000 \\
\hline
\end{tabular}

It is known that the $t$-value for the motive for using social media is 13,757 with a probability (sig) of 0,000 while the decision making is based on the following conditions:

Hypothesis:

Ho: There is no significant effect of the motive for using social media on the impact of using social media

$\mathrm{H1}$ : There is a significant influence of the motive for using social media on the impact of using social media

Decision Criteria:

a. Ho is accepted if the probability value (sig) $>0.005$

b. Reject if Ho if the probability value (sig) $<0.005$

Thus in this study that is a significant influence of the motive of using social media on the impact of the use to social media among housewives in the city of Cirebon, West Java, Indonesia. T test results there are different tests with a correlation of $0.543 \mathrm{sig}$. (2-tailed) $0.00<$ from 0.005

\subsection{CONCLUSIONS}

1.6.1. Identify Social Media User Profile by Housewives in Cirebon, Indonesia

Indonesia is mostly from Cirebon, living in Cirebon district, with a Bachelor's degree, with a home content income of Rp. 5,000,000., And above with 3 households living in the same house. The use of social media in the form of Whatsapp and Instagram, with a usage time of about five hours.

1.6.2. The motives of social media usage among housewives in Cirebon, Indonesia.

Motif for using Social Media is more dominant as a communication media itself, namely in interacting socially with the environment in this case with fellow social media users.

1.6.3. Assess the effects of social media usage among housewives in Cirebon, Indonesia. know the activities of fellow social media users. This they do to support each other and share any activities that have been, are or will be done, in addition to seeking health tips and tips on taking care of the household that in the end they live and enjoy their daily activities, can interact well through the media socially, carry out important activities, they can overcome their problems well, live a good life, believe in their future, believe that they are respected by others. Their feelings are often positive and often good, often pleasant, often happy, and never angry.

\section{REFERENCES}

https://marketeers.com/survei-perempuan-mendominasi-media-sosial/ (acces, Juny $5^{\text {th }}, 2019$ )

Malaymail Online. 14 August 2016. Ahliakademik: Tagih internet lima jam sehariancampsikologibelia. Retrieved from http://www.themalaymailonline.com/projekmmo/berita/article/ahli-akademik-tagih-internet-lima-jam-sehariancam-psikologi-belia\#sthash.qTJym6eJ.dpuf.

Hamid, N.A., Ishak, M.S. \& Yazam, S.S.N.M. (2015). Facebook, YouTube and Instagram: Exploring their effects on undergraduate students' personality traits. Journal of Social Media in Society, 4(2), 138-165. 
Rahi, B. (2015). Media Watch. 6(3), p.318-325. DOI: 10.15655/mw/2015/v6i3/77894.

Wulandari, dkk., 2014., Penggunaan Jejaring Sosial Path oleh Ibu Rumah Tangga di Kota Bandung., Proseding Jurnalistik., 1 (2), 115-120.

Ging, Y. T. (2015, May 17). Social media allows housewives to tap into their entrepreneurial spirit...and earn big bucks. The Malay Mail. Retrieved from http://www.themalaymailonline.com/malaysia/article/social-media-allowshousewives-to-tap-into-their-entrepreneurial-spiritand

Fischer, E., Reuber, A.R., Social interaction via new social media: (How) can interactions on Twitter affect effectual thinking and behavior? J. Bus. Venturing (2010), doi:10.1016/j.jbusvent.2010.09.002

Kim, W., Jeong, O.-R., \& Lee, S.-W. (2010). On social websites. Information Systems, 35, 215-236.

Kaplan, A. M., \&Haenlein, M. (2010). Users of the world, unite! The challenges and opportunities of Social Media.Business Horizons, 53, 59-68

Kietzmann, J.H., Hermkens, K., McCarthy, I.P. and Silvestre, B.S. (2011).Social media? Get serious! Understanding the functional building blocks of social media.Business Horizons, In press.

Hicks, R. (2010).Are women better at understanding social media? Retrieved 26 ${ }^{\text {th }}$ March 2011 from http://www.futuregov.asia/articles/2010/dec/06/are-women-better-men-using-social-media/

Pew Internet Research.(2017). Social media fact sheet. Retrieved on 16 ${ }^{\text {th }}$ March 2017 from http://www.pewinternet.org/fact-sheet/social-media/

Lenhart, A. (2009). Teens and social media: An overview. Retrieved 19 ${ }^{\text {th }}$ March 2011 from http://isites.harvard.edu/fs/docs/icb.topic786630.files/Teens\%20Social\%20Media\%20and\%20Health\%20-

\%20NYPH\%20Dept\%20Pew\%20Internet.pdf

Maul, K. (2010). Study finds women's social media use up. PrWeek.

Hicks, R. (2010).Are women better at understanding social media? Retrieved 26 ${ }^{\text {th }}$ March 2011 from http://www.futuregov.asia/articles/2010/dec/06/are-women-better-men-using-social-media/

Sei-Ching, J.S. (2016). Social media and problematic everyday life information-seeking outcomes: Differences across use frequency, gender, and problem-solving styles, Journal of The Association for Information Science and Technology, 67(8):1793-1807.

Al-Saggaf, Y. (2017). Information sharing on Facebook by Alone, Single and Lonely Female Users. SEARCH: The Journal of the South East Asia Research Centre for Communications and Humanities, 9(1), 97-116.

Odine, M. (2013).Role of social media in the empowerment of Arab women. Available: http://www.globalmediajournal.com/open-access/role-of-social-media-in-the-empowerment-of-arab-women.pdf

Divatia, A. \& Patel, M. (2017). A study on selected social media applications usage practices of homemakers, International Journal of Social Science and Humanity, 7(6), 336-343.

Blumler, J.G. (1979). The role of theory in uses and gratifications research. Communication Research, 6, 9-36.

Blumler, J.G., \& Katz, E. (Eds.). (1974). The uses of mass communications: Current perspectives on gratifications research. Beverly Hills, CA: Sage.

Palmgreen, P. (1984). Uses and gratifications: A theoretical perspective. In R.N. Bostrom (Ed.), Communication Yearbook 8 (pp. 20-55). Newbury Park, CA: Sage.

Rosengren, K.E., Wenner, L.A., \&Palmgreen, P. (Eds.). (1985). Media gratifications research: Current perspectives. Newbury Park, CA: Sage. 
Rubin, A.M. (2002). The uses-and-gratifications perspective of media effects. In J. Bryant \& D. Zillmann (Eds.), Media effects: Advances in theory and research (2nd ed., pp. 525-548). Mahwah, NJ: Lawrence Erlbaum Associates.

Rubin, A.M., \&Windahl, S. (1986). The uses and dependency model of mass communication. Critical Studies in Mass Communication, 3, 184-199.

Windahl, S. (1981).Uses and gratifications at the crossroads.In G.C.Wilhoit\& H.de Bock (Eds.), Mass communication review yearbook (Vol. 2, pp. 174-185). Newbury Park, CA: Sage.

Harris, R. J. (2008). A cognitive psychology of mass communication. $4^{\text {th }} \mathrm{ed}$. New Jersey: Lawrence Erlbaum Associates.

Quan-Haase, A., \& Young, A. L. (2010). Uses and Gratifications of Social Media: A Comparison of Facebook and Instant Messaging. Bulletin of Science, Technology \& Society, 30(5), 350-361. https://doi.org/10.1177/0270467610380009

Alhabash, S., Park, H., Kononova, A., Chiang, Y. \& Wise, K. (2012). Exploring the motivations of Facebook use in Taiwan.

Kuss, D.J. \& Griffiths, M.D. (2011).Online social networking and addiction - A review of the psychological literature.International Journal of Environmental Research in Public Health, 8(9):3528-52. doi: 10.3390/ijerph8093528.

Tanta, I., Mihovilović, M. \&Sablić, Z. (2014).Uses and gratification theory - Why adolescents use Facebook? Medij.istraž., 20(2), 85-110.

Whiting, A. \& Williams, D. (2013). Why people use social media: A uses and gratifications approach. Qualitative Market Research: An International Journal, 16(4), 362-369. https://doi.org/10.1108/QMR-06-2013-0041.

Cheung Ting Ting.(2014). A Study of Motives, Usage, Self-presentation and Number of Followers on Instagram. Cyberpsychology, Behavior, and Social Networking, 15(6), 304-311. doi: 10.1089/cyber.2011.0611.

Tripathi, S. \& Al-Shahri, M. (2016). Omani Community in Digital Age: A study of Omani Woman Using Back Channel Media to Empower Themselves for Frontline Entrepreneurship

Divatia, A. \& Patel, M. (2017). A study on selected social media applications usage practices of homemakers, International Journal of Social Science and Humanity, 7(6), 336-343.

Barthwal, A. S. D. T. (2014). Understanding the pattern of usage of social networking sites in India. Ojas Expanding Knowledge Horizone, 76.

Coghlan, A. (2015). Tourism and health: using positive psychology principles to maximize participants' wellbeing outcomes _ a design concept for charity challenge tourism. Journal of Sustainable Tourism, 23(3), 382_400, http://dx.doi.org/10.1080/09669582.2014.986489.

Diener, E., Wirtz, D., Tov, W., Kim-Prieto, C., Choi, D. Oishi, S. \&Biswas-Diener, R. (2010) Flourishing scale and scale of positive and negative experience (SPANE). Social Indicators Research, 97:143-156.

Hoffman, D.L. \& Novak, T.P. (2012). Why do people use social media? Empirical findings and a new theoretical framework for social media goal pursuit. Retrieved 23 ${ }^{\text {rd }}$ January 2017, from https://papers.ssrn.com/sol3/papers.cfm?abstract_id=1989586

Tong KK, Wang YY (2017) Validation of the flourishing scale and scale of positive and negative experience in a Chinese community sample. PLoS ONE 12(8): e0181616. https://doi.org/10.1371/journal.pone.0181616

Yang, C. \& Liu, D. (2017). Motives matter: Motives for playing Poke'mon Go and implications for well-being. Cyberpsychology, Behavior, and Social Networking, 20(1), 52-57. DOI: 10.1089/cyber.2016.0562.

Kim, W., Jeong, O.-R., \& Lee, S.-W. (2010). On social websites. Information Systems, 35, 215-236. 
Hair, J. F., Black, W. C., Babin, B. J. \& Anderson, R. E. (2010).Multivariate data analysis. (7 ed.). Upper Saddle River, NJ: Pearson Prentice Hall.

Tabachnick, B. \&Fidell, L. (2001). Using multivariate statistics. $4^{\text {th }}$ ed. Needham Height, MA, USA: Allyn\& Bacon.

Singgih, Santoso., 2014., Panduan Lengkap SPSS Versi 20, Edisi Revisi, Jakarta : Gramedia

Freitas, H., Oliveira, M., Jenkins, M. \&Popjoy, Ao.(1998). The Focus Group, a qualitative research method. Retrieved on $10^{\text {th }}$ November 2018 from gianti.ea.ufrgs.br/files/artigos/1998/1998_079_ISRC.pdf

Gill, P., Stewart, K., Treasure, E. \& Chadwick, B. (2008). Methods of data collection in qualitative research: interviews and focus groups. British Dental Journal, 204(6):291-295. doi: 10.1038/bdj.2008.192. 